\title{
A NEW ACARALOX SPECIES \\ (ACARI: PROSTIGMATA: ERIOPHYOIDEA) \\ ON VERBENA OFFICINALIS L. FROM HUNGARY
}

\begin{abstract}
GÉZA RIPKA
National Food Chain Safety Office, Directorate of Plant Protection, Soil Conservation and Agri-environment, Department of Pest Management Development and Coordination H-1118 Budapest, Budaörsi út 141-145, Hungary. E-mail: RipkaG@nebih.gov.hu
\end{abstract}

The female, male and nymph of Acaralox bognari sp. n., associated with Verbena officinalis (Verbenaceae), are described from Hungary. Taxonomically relevant morphological details are illustrated and the species is diagnosed from the similar representatives of the genus.

Key words: Eriophyidae, Acaralox, common vervain, Verbenaceae, Hungary.

\section{INTRODUCTION}

In the Hungarian flora the family Verbenaceae is represented by one genus (KIRÁLy 2009). The common vervain (Verbena officinalis L.) (Verbenaceae) is one of the only two species of Verbena native to Hungary. It is a perennial (hemicryptophyte) or a hemitherophyte plant. Out of over 4400 known eriophyoid species (ZHANg et al. 2011) the genus Acaralox Keifer (Acari: Eriophyoidea: Eriophyidae) is a small genus represented by six species worldwide and found on plant families Poaceae, Rosaceae and Avicenniaceae. In Europe, the genus Acaralox currently includes two described species: Acaralox arundinaceus Skoracka and Acaralox croatiae Skoracka, Labrzycka et Rector (SкоRаска 2002, Sковаска et al. 2009). In the Hungarian fauna no Acaralox species have been reported so far (RIPKA 2007, 2008), and no Acaralox species have hitherto been found on common vervain (Verbena officinalis) in the world (Amrine \& Stasny 1994, 1996, Davis et al. 1982, Liv et al. 2013). Just an other species, Aculus verbenae (Keifer) is known from Verbena sp. (Verbenaceae) in Mexico (KeIfer 1977).

\section{MATERIAL AND METHODS}

The eriophyoid mite fauna of common vervain (Verbena officinalis L.) was studied from plant samples collected in Budapest XVII, Alsó-Rákoshegy, Central Hungary, in June and July 2014. The plant material (upper and lower surfaces of the leaves, petioles, stems, 
buds, flowers, etc.) was collected in plastic bags, returned to the laboratory and examined with a dissecting stereomicroscope (Zeiss Stemi 2000-C). The mites were cleared in lactic acid (for 4-6 weeks at room temperature to obtain the desired extent of clearing) and mounted on glass microscopic slides using Keifer's F-medium with sorbitol (KeIFER 1975). The slide preparations were dried for $4-6$ weeks at room temperature then sealed with commercial nail varnish (UpTON 1991). Figures were drawn and measurements were made using a phase contrast Nikon Eclipse E 600 microscope equipped with a Nikon YIDT drawing tube. The generic classification is based on AmRine et al. (2003). The terminology and setal notation used in the morphological descriptions follows Lindeuist (1996). The number of measured specimens ( $\mathrm{n}$ ) is given within parentheses in the description. All measurements of mites were made according to AMrine and MANson (1996) using an ocular micrometer eyepiece, and are given in micrometers $(\mu \mathrm{m})$. The holotype measurement precedes the corresponding range of the paratypes, in parentheses. For males and immature stages, only the ranges are given. Measurements and means are rounded off to the nearest integer, if necessary. All measurements, unless specified otherwise, refer to the length of the structure. Because some measurements of the type could not be taken, due to the mounting position, the mean measurements are reported.

The scientific name of host plant is used according to KiráLY (2009) and KIRÁLy et al. (2011).

\section{RESULTS}

\section{Superfamily ERIOPHYOIDEA Nalepa, 1898 \\ Family ERIOPHYIDAE Nalepa, 1898 \\ Genus Acaralox Keifer, 1966 \\ Acaralox bognari sp. $n$.}

(Fig. 1)

Diagnosis - Body vermiform with wide dorsal furrow; prodorsal shield pattern composed of a short, incomplete median line on rear third and two complete sinusoid admedian lines beginning close to posterior margin of the shield; one complete and one incomplete submedian lines on each side; considerably long dorsal palp genual setae $d$; empodium entire, 7-rayed; coxisternum I forming a median sternal line, coxisternae I and II with longitudinal lines; female genital coverflap with longitudinal ridges; subequal microtuberculate dorsal and ventral semiannuli.

Description - Female $(\mathrm{n}=10)$. Body whitish, vermiform, with wide dorsal furrow ending at annulus of opisthosomal setae $e, 259$ (198-269), 56 (43-56) wide, 57 (54-60) thick. Gnathosoma 20 (18-23), projecting obliquely downwards; chelicerae 19 (15-20), dorsal palp genual setae $d 9$ (8-10), simple, pedipalp coxal setae ep 3 (2-3). Prodorsal shield 41 (33-43), 42 (33-42) wide, semicircular; shield pattern composed of a short, incomplete median line on rear third $(1 / 3-3 / 8)$ and two complete admedian lines beginning close to posterior margin of the shield, diverging to rear margin; one complete and one incomplete submedian lines on each side. First submedian lines subparallel to admedian lines on anterior three quar- 
ters, then curving out ahead of scapular tubercles toward outer side of tubercles setae sc. Second submedian lines subparallel to lateral margin of shield. Posteriorly few dashes between admedian and first submedian lines, few dashes and granules between submedian lines, one dash between second submedian lines and shield margin. Tubercles of scapular setae $s c$ on the rear shield margin, 27 (21-27) apart, diverging, scapular setae $s c$ 52 (45-65), directed to backward. Fine granules laterally in rows between shield margin and dorsal coxae of legs I and II.

Leg I 35 (29-36), femur 12 (12-13), basiventral femoral setae bv 14 (10-14), genu 6 (6-8), antaxial genual setae $l^{\prime \prime} 28(25-28)$, tibia $7(6-7)$, paraxial tibial setae $l^{\prime}$ located at $1 / 3$ $(1 / 3-3 / 8)$ from dorsal base, $11(10-12)$, very thin, tarsus $8(6-8)$, paraxial, unguinal tarsal setae $u^{\prime} 6$ (5-6), solenidion $\omega 10$ (9-10), blunt, curved, empodium simple, bilaterally symmetrical, 8 (8-9), with 7 paired rays. Leg II (hind leg) 32 (28-33), femur 11 (10-12), basiventral femoral setae $b v 15$ (13-20), genu 5 (5-6), antaxial genual setae $l$ " 13 (10-13) very thin, tibia 6 (5-6), tarsus 7 (5-7), paraxial, unguinal tarsal setae $u^{\prime} 5$ (4-5), solenidion $\omega 10$ (9-10) subequal with solenidion $\omega$ on leg I, blunt, curved, empodium simple, bilaterally symmetrical, 9 (8-9), with 7 paired rays. Small spinules distally on femora and tibiae on both leg pairs.

Coxisternae I and II with several longitudinal lines and dashes; anterolateral setae on coxisternum I, setae $1 b 8(8-10)$, tubercles setae $1 b 13$ (11-13) apart, proximal setae on coxisternum I, setae 1a 20 (19-27), tubercles setae 1a 9 (8-10) apart, proximal setae on coxisternum II, setae $2 a 39$ (38-46), tubercles setae $2 a 27$ (24-27) apart. Prosternal apodeme distinct 11 (10-13). Coxigenital area with 8 (7-9) microtuberculate annuli.

Opisthosoma with 72 (69-76) dorsal, 73 (64-78) ventral annuli. Dorsal annuli with small pointed microtubercles on rear annular margin. On ventral annuli the microtubercles a little larger, round and pointed close to the rear annular margin, except for the 5-6 ventral annuli from caudal lobes, which are elongate and linear. Opisthosomal setae $c 240$ (38-50), on annulus 11 (10-12), 51 (41-51) apart; opisthosomal setae $d 60$ (50-61), on annulus 25 (21-25), 34 (30-37) apart; opisthosomal setae $e 35$ (30-53), on annulus 43 (36-44), 20 (18-22) apart; opisthosomal setae $f 29$ (28-33), on annulus 69 (60-74), or 5 (5) from the rear, 19 (17-23) apart, all very thin at apex. Opisthosomal setae $h 273$ (73-81), 10 (10-11) apart; opisthosomal setae $h 15$ (3-5), 7 (5-8) apart. Caudal lobes normal in size and shape.

Genital plate 20 (17-20), 25 (20-25) wide. Female genital coverflap with 9 (9-12) longitudinal ridges; coxisternal III setae $3 a 18$ (17-20) apart, 19 (19-22).

Male $(n=2)$. Similar to the female, whitish, with wide dorsal furrow, 170-179, 53 wide, 38 thick. Gnathosoma 18-20, projecting obliquely downwards; chelicerae 15, dorsal palp genual setae $d 8-9$, simple. Prodorsal shield 33-36, 41-44 wide, semicircular; shield pattern composed of a short, incomplete median line on rear third and two complete admedian lines beginning close to posterior margin of the shield; one complete and one incomplete submedian lines on each side. First submedian lines subparallel to admedian lines on anterior three quarters, then curving out ahead of scapular tubercles toward outer side of tubercles setae $s c$. Posteriorly few dashes between admedian and submedian lines, few dashes and granules between submedian lines, one dash between second submedian lines and shield margin. Tubercles of scapular setae $s c$ on the rear shield margin, 26 apart, diverging, scapular setae sc 37-38, directed to backward. Fine granules laterally in rows between shield margin and dorsal coxae of legs I and II.

Legs with all usual segments and setae present. Leg I 31-33, femur 10-11, basiventral femoral seta $b v 10$, genu 5-6, antaxial genual setae $l^{\prime \prime} 25$, tibia 8, paraxial tibial setae $l^{\prime}$ located at $3 / 8-1 / 2$ from dorsal base, 8 , very thin, tarsus 8 , solenidion $\omega 9-10$, blunt, curved, empodium simple, bilaterally symmetrical, $7-8$, with 6 paired rays. Leg II 29-30, femur 8-10, 

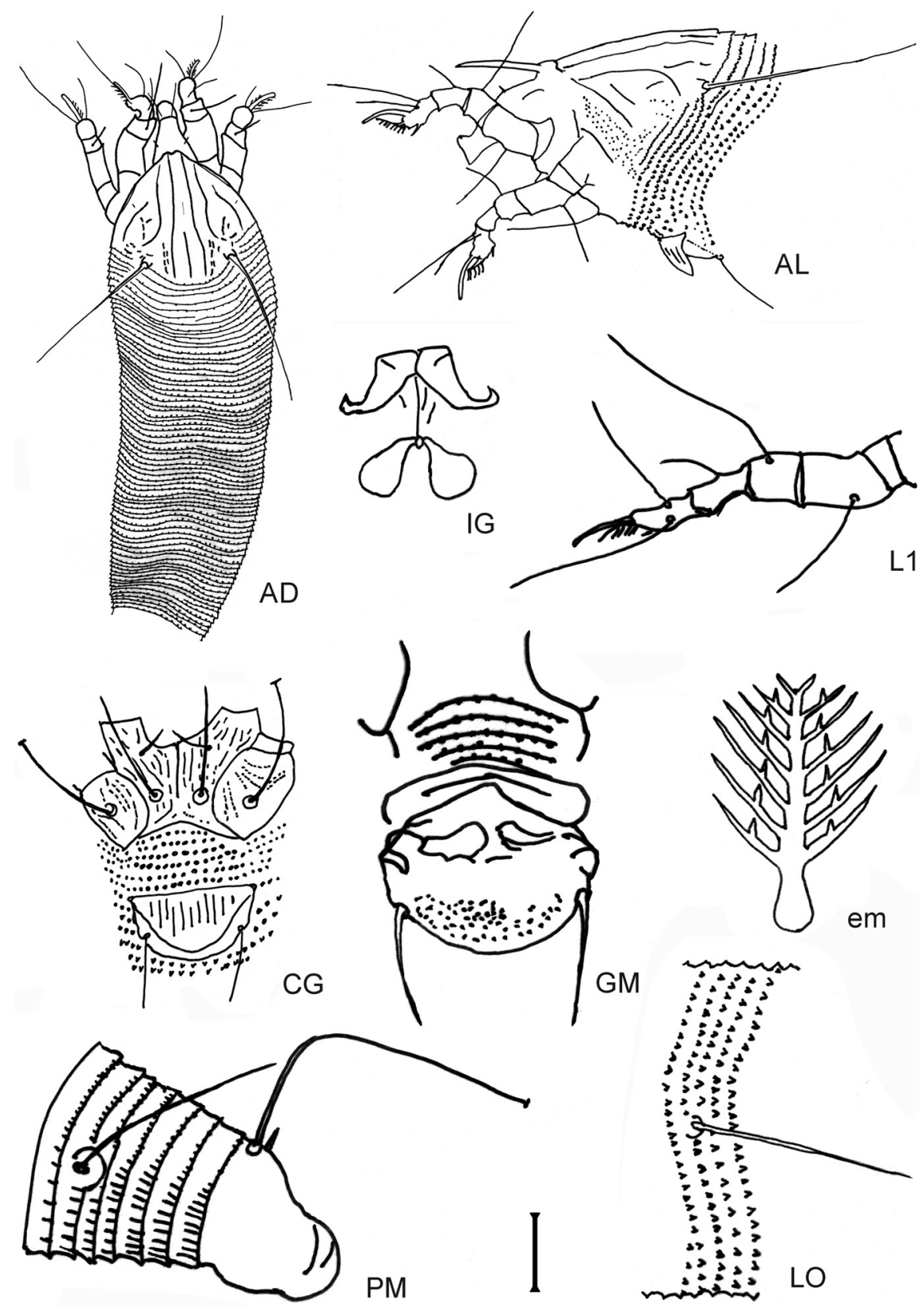

Fig. 1. Acaralox bognari sp. n., semischematic drawings: $A D=$ antero-dorsal mite, $A L=$ lateral view of anterior body region, $C G=$ female coxigenital region, em = empodium of leg $\mathrm{I}$, $\mathrm{GM}=$ genital region of male, IG = internal female genitalia; $\mathrm{L} 1=$ leg I, LO = lateral view of annuli, $\mathrm{PM}=$ lateral view of posterior opisthosoma. Scale bar: $24 \mu \mathrm{m}$ for AD; $20 \mu \mathrm{m}$ for AL; $19 \mu \mathrm{m}$ for LO; $16 \mu \mathrm{m}$ for CG; $12 \mu \mathrm{m}$ for IG; $10 \mu \mathrm{m}$ for GM, $9 \mu \mathrm{m}$ for L1, PM; $2.7 \mu \mathrm{m}$ for em. 
basiventral femoral setae $b v$ 18-25, genu 6, antaxial genual setae $l^{\prime \prime} 8-10$ very thin, tibia 5, tarsus $6-7$, solenidion $\omega 9$, blunt, curved, empodium simple, bilaterally symmetrical, 7-8, with 6 paired rays. Small spinules distally on femora and tibiae on both leg pairs.

Coxisternae I and II with several longitudinal lines; anterolateral setae on coxisternum I, setae $1 b 6-7$, tubercles setae $1 b 11$ apart, proximal setae on coxisternum I, setae $1 a$ 15-19, tubercles setae $1 a 9$ apart, proximal setae $2 a$ on coxisternum II 18-36, tubercles setae $2 a 24$ apart. Prosternal apodeme distinct $8-10$. Coxigenital area with $4-5$ microtuberculate annuli.

Opisthosoma with 57-59 dorsal, 64 ventral annuli. Dorsal annuli with pointed microtubercles on rear annular margin. On ventral annuli the microtubercles larger, round and pointed close to the rear annular margin, except for the $4-5$ ventral annuli from caudal lobes, which are elongate and linear. Opisthosomal setae $c 2$ 38-39, on annulus 10-12, 43 apart; opisthosomal setae $d$ 38-43, on annulus 21-22, 33 apart; opisthosomal setae $e$ 15, on annulus 34-37, 16 apart; opisthosomal setae $f 25-28$, on annulus 59, or 5 from the rear, 18 apart, all very thin at apex. Opisthosomal setae $h 2$ 56, 10 apart; opisthosomal setae $h 1$ 3, 7 apart. Caudal lobes normal in size and shape.

Genital plate 17-18, 18-20 wide; coxisternal III setae 3a 17 apart, 12-14; surface near the genital opening with minute granules.

Nymph ( $\mathrm{n}=2)$. Similar to the female, whitish, 182-188, 43-46 thick. Gnathosoma 20-23, projecting obliquely downwards; chelicerae 18. Prodorsal shield 32-35, semicircular. Scapular setae sc 30-35, directed to backward. Fine granules laterally in rows between shield margin and dorsal coxae of legs I and II.

Legs with all usual segments and setae present. Leg I 28-29, femur 10, basiventral femoral setae $b v 7$, genu 3-4, antaxial genual setae $l$ " 23-24, tibia 5, paraxial tibial setae $l^{\prime}$ located at $1 / 3-3 / 8$ from dorsal base, $8-9$, very thin, tarsus 5 , solenidion $\omega 7$, blunt, curved, empodium simple, bilaterally symmetrical, 6-7, with 6 paired rays. Leg II 23-24, femur 8, basiventral femoral setae bv 10-12, genu 3-4, tibia 4, tarsus 4-5, solenidion $\omega 7$, blunt, curved, empodium simple, bilaterally symmetrical, 6-7, with 6 paired rays.

Proximal setae on coxisternum II, setae $2 a$ 25-30. Coxisternal III setae $3 a 10$.

Opisthosoma with 55-58 dorsal, 57-60 ventral annuli.

Host plant - Common vervain or common verbena or herb of the cross, Verbena officinalis L. (Verbenaceae) which is a widely distributed perennial herb in Hungary.

Relationship to the host plant. This vagrant mite was found on lower side of the leaves, close to the veins, among the sparse hairs. No damage symptoms were observed.

Locality - Budapest XVII, Alsó-Rákoshegy, Homoki-szőlők, 151 m elev.; $47^{\circ} 27^{\prime} 02.8^{\prime \prime} \mathrm{N}, 19^{\circ} 14^{\prime} 05.0^{\prime \prime} \mathrm{E}$. The host grows in roadside vegetation.

Type material - Holotype female circled with black ink among 5 females on one slide, 2 July 2014, slide \# 1348c, coll. G. Ripka. Paratypes: 6 females and 1 male (slide \# 1340a), 20 June 2014, locality same as for holotype, coll. G. Ripka, and 4 females and 1 nymph (slide \# 1348b), 8 females and 1 nymph (slide \# 1348e), 2 July 2014, locality same as for holotype, deposited in the Department of Pest Management Development and Coordination, Directorate of Plant Protection, Soil Conservation and Agri-environment, National Food Chain Safety Office, Budapest, Hungary. 
Etymology - The species is named after the late Prof. Dr. Sándor Bognár, who was an eminent acarologist and head of the Department of Plant Protection, University of Horticulture of Budapest, and the teacher of the author. He lived in that district of Budapest, XVII, Rákoshegy, which is actually the type locality of A. bognari sp. n.

Differential diagnosis - To date, six Acaralox species have been reported in the world: A. harperi Keifer, 1966, described from Cercocarpus montanus (Rosaceae); A. bambusae Kuang, 2002, from Bambusa sp. (Poaceae); A. arundinaceus Skoracka, 2002, from Phalaris arundinacea (Poaceae); A. farsi Kamali et Soleimani, 2006, from Cynodon dactylon (Poaceae); A. croatiae Skoracka, Labrzycka et Rector, 2009, from Molinia caerulea (as M. coerulea) and Calamagrostis epigeios (both in the family Poaceae); A. marinae Li, 2009, from Avicennia marina (Avicenniaceae, formerly Acanthaceae) (Keifer 1966, Kuang 2002, Skoracka 2002, Kamali \& Soleimani 2006, Skoracka et al. 2009, Li et al. 2009).

The new species described herein is close to Acaralox croatiae (SKоRAcKA et al. 2009), but it is differentiated by shape and dimension of prodorsal shield, e.g. semicircular with subequal length and width (41:42) (subtriangular, shorter and wider (35:48) in A. croatiae), distinct prosternal apodeme (indistinct or missing in A. croatiae), more numerous dorsal (69-76) and ventral annuli (64-78) (47-56 and 54-61, respectively in A. croatiae), longer opisthosomal setae $e 35$ (30-53) (14 (10-14) in A. croatiae), tarsus slightly longer than tibia on legs I and II (tibia longer than tarsus on legs I and II in A. croatiae).

The new species is similar to A. marinae (Li, Lan et Wei, 2009). The prodorsal shield with many short lines laterally, scapular setae $s c 7.5$, coxal area with granules and empodium 5-rayed. Whereas characters of A. bognari n. sp. are the one dash between second submedian lines and shield margin, scapular setae sc 50 (49-56), coxisternae I and II with several longitudinal lines and empodium 7-rayed.

Acknowledgements - Thanks are expressed to Drs Xiao-Feng Xue (Department of Entomology, Nanjing Agricultural University, Nanjing, Jiangsu, China) and Anna Skoracka (Department of Animal Taxonomy and Ecology, Adam Mickiewicz University, Institute of Environmental Biology, Poznań, Poland) for providing reprints of some papers which were not otherwise obtainable by the author. The author is grateful to Mr Ede Böszörményi (National Food Chain Safety Office, Budapest, Hungary) for the linguistic revision of the manuscript, Mr Balázs Herzog (National Food Chain Safety Office, Budapest) and $\mathrm{Mr}$ Miklós Bozsó (National Food Chain Safety Office, Budapest) for their assistance in preparing the drawings. 


\section{REFERENCES}

Amrine, J. W., JR. \& Manson, D. C. M. (1996) Preparation, mounting and descriptive study of eriophyoid mites. Pp. 383-396. In: Lindquist, E. E., SAbelis, M. W. \& Bruin, J. (eds): Eriophyoid mites - their biology, natural enemies and control. World Crop Pests, 6. Elsevier, Amsterdam.

Amrine, J. W., Jr. \& Stasny, T. A. (1994) Catalog of the Eriophyoidea (Acarina: Prostigmata) of the World. Indira Publishing House, West Bloomfield, USA. ix + 798 pp.

Amrine, J. W., Jr. \& Stasny, T. A. (1996) Corrections to the catalog of the Eriophyoidea (Acarina: Prostigmata) of the World. International Journal of Acarology 22: 295-304. doi: 10.1080/01647959608684108

Amrine, J. W., Jr., Stasny, T. A. H. \& Flechtmann, C. H. W. (2003) Revised keys to World genera of Eriophyoidea (Acari: Prostigmata). Indira Publishing House, West Bloomfield, USA. iv +244 pp.

Davis, R., Flechtmann, C. H. W., Boczek, J. H. \& Barké, H. E. (1982) Catalogue of Eriophyid mites (Acari: Eriophyoidea). Warsaw Agricultural University Press, Warsaw, 254 pp.

DE Lillo, E. (2012) Fauna Europaea: Eriophyoidea. In: Magowski, W. Ł. (ed.): Fauna Europaea: Acari: Acariformes. Fauna Europaea version. 2.4. http://www.faunaeur.org (accessed 17/12/2014)

Kamali, H. \& Soleimani, R. (2006) A new Acaralox species (Acari: Eriophyidae) from Bermudagrass in Iran. International Journal of Acarology 32: 185-187.

Keifer, H. H. (1966) Eriophyid studies B-21. Bureau of Entomology, California Department of Agriculture, Sacramento, $24 \mathrm{pp}$.

Keifer, H. H. (1975) Eriophyoidea Nalepa. Pp. 327-533. In: Jeppson, L. R., Keifer, H. H. \& BAKER, E. W. (eds): Mites injurious to economic plants. University of California Press, Berkeley, Los Angeles.

KeIfer, H. H. (1977) Eriophyid studies C-13. Agricultural Research Service, USDA, USA, 24 pp.

Király, G. (ed.) (2009) Új magyar füvészkönyv. Magyarország hajtásos növényei. Határozókulcsok. Aggteleki Nemzeti Park Igazgatóság, Jósvafö, 616 pp. [New Hungarian Herbal. The vascular plants of Hungary. Identification key.] [in Hungarian]

Király, G., Virók, V. \& Molnár, V. A. (eds) (2011) Új magyar füvészkönyv. Magyarország hajtásos növényei. Ábrák. Aggteleki Nemzeti Park Igazgatóság, Jósvafö, 676 pp. [New Hungarian Herbal. The Vascular Plants of Hungary. Illustrations.]. [in Hungarian]

Kuang, H.-Y. (2002) Two new species of Eriophyinae from China (Acari: Eriophyidae). Acta Entomologica Sinica 45: 115-117.

Lindquist, E. E. (1996) External anatomy and notation of structures. Pp. 3-31. In: Lindquist, E. E., SAbelis, M. W. \& Bruin, J. (eds): Eriophyoid mites - their biology, natural enemies and control. World Crop Pests, 6. Elsevier, Amsterdam.

LI, D.-W., LAN, X. \& WEI, S.-G. (2009) A new species of Acaralox (Acari, Eriophyoidea) infesting mangrove, Avicennia marina (Forsk.) Vierh., from China. Acta Zootaxonomica Sinica 34: 868-870.

LiU, D., YI, T.-C., XU, Y. \& Zhang, Z.-Q. (2013) Hotspots of new species discovery: new mite species described during 2007 to 2012. Zootaxa 3663: 1-102. doi: 10.11646/zootaxa. 3663.1.1

RIPKA, G. (2007) Checklist of the eriophyoid mite fauna of Hungary (Acari: Prostigmata: Eriophyoidea). Acta Phytopathologica et Entomologica Hungarica 42: 59-142. doi: 101556/APhyt.42.2007.1.7 
RIPKA, G. (2008) Additional data to the eriophyoid mite fauna of Hungary (Acari: Prostigmata: Eriophyoidea). Acta Phytopathologica et Entomologica Hungarica 43: 143-161. doi: 101556/APhyt.43.2008.1.15

RipKA, G. (2014) Eriophyoid mites (Acari: Prostigmata: Eriophyoidea) from Hungary: a new species on Agrimonia eupatoria (Rosaceae) and new record on Convolvulus arvensis (Convolvulaceae). Zootaxa 3900: 263-270. doi: 10.11646/zootaxa.3900.2.6

SкоrackA, A. (2002) Two new species of eriophyoid mites (Acari: Eriophyoidea) from grasses in Poland. Zootaxa 54: 1-15.

Sкoracka, A., Labrzycka, A. \& Rector, B. G. (2009) Three new species of eriophyoid mites (Acari: Prostigmata: Eriophyoidea) from grass hosts in Croatia. Annals of the Entomological Society of America 102: 12-19. doi: 10.1603/008.102.0102

Upton, M. S. (1991) Methods for collecting, preserving, and studying insects and allied forms. The Australian Entomological Society, Brisbane. Misc. Publ. No. 3. v + 86 pp.

Zhang, Z.-Q., Fan, Q.-H., Pesic, V., Smit, H., Bochkov, A. V., Khaustov, A. A., Baker, A., Wohltmann, A., Wen, T., Amrine, J. W., Beron, P., Lin, J., Gabrys, G. \& Husband, R. (2011) Order Trombidiformes Reuter, 1909. In: ZhANG, Z.-Q. (ed.): Animal biodiversity: An introduction to higher-level classification and taxonomic richness. Zootaxa 3148: 7-12.

Revised version received March 16, 2015, accepted July 6, 2015, published August 14, 2015 